\title{
Detection of clonally related vanB2-containing Enterococcus faecium strains in two Spanish hospitals
}

Correspondence

Carmen Torres

carmen.torres@daa.unirioja.es

Received 8 February 2006

Accepted 17 May 2006

\author{
Carmen Torres, ${ }_{1}^{1}$ Susanna Escobar, ${ }^{2}$ Aránzazu Portillo, ${ }^{1,3}$ Luis Torres, ${ }^{2}$ \\ Antonio Rezusta, ${ }^{2}$ Fernanda Ruiz-Larrea, ${ }^{1}$ Maria José Revillo, ${ }^{2}$ \\ Carmen Aspiroz $^{4}$ and Myriam Zarazaga ${ }^{1}$ \\ 1'Área Bioquímica y Biología Molecular, Universidad de La Rioja, Madre de Dios 51, Logroño \\ 26006, Spain \\ ${ }^{2}$ Hospital Universitario Miguel Servet, Zaragoza, Spain \\ ${ }^{3}$ Área de Enfermedades Infecciosas, Hospital de La Rioja, Logroño, Spain \\ ${ }^{4}$ Hospital Royo Villanova, Zaragoza, Spain
}

\section{INTRODUCTION}

Different mechanisms of vancomycin resistance have been detected in enterococci ( $v a n A, v a n B, v a n C, v a n D, v a n E$ and vanG) (Cetinkaya et al., 2000; Gholizadeh \& Courvalin, 2000; Murray, 1997; Perichon et al., 1997; Woodford, 2001). The $v a n B$ genotype is characterized by acquired inducible resistance to various levels of vancomycin and susceptibility to teicoplanin (Quintiliani et al., 1993). It is determined by a cluster of genes, $\operatorname{van}_{\mathrm{B}}, \operatorname{van}_{\mathrm{B}}, \operatorname{van}_{\mathrm{B}}, \operatorname{van} W, \operatorname{van}_{\mathrm{B}}$, $\operatorname{vanB}$ and $v a n X_{B}$. Three different subtypes of the vanB gene have been documented, vanB1, vanB2 and vanB3, based on sequence variability in the vanB ligase gene (Dahl et al., 1999). The vanB2 subtype has been found in human enterococcal strains from different countries (Dahl et al., 1999, 2000; Gold et al., 1993; Granlund et al., 2006; Kawalec et al., 2001; Lee et al., 2001; Lu et al., 2001, 2005; Mato et al., 1996; McGregor \& Young, 2000; McGregor et al., 2001;

Abbreviations: ICU, intensive care unit; VREF-VBP, vancomycinresistant Enterococcus faecium strains with VanB phenotype.
Simonsen et al., 1998). In Spain, there has been one previous report on the detection of a vanB2-containing Enterococcus faecium clinical strain (Lorenzo-Díaz et al., 2004) and one on the detection of a vanB2-containing Enterococcus hirae strain from a faecal sample of a healthy pig (Torres et al., 2003). Recently, the vanB2 gene cluster associated with a Tn5382-like transposon has been found in a Clostridium strain from human faeces in Canada (Domingo et al., 2005).

Over a 1 year period, a series of clinical and intestinal vancomycin-resistant $E$. faecium strains with VanB phenotype (VREF-VBP) were recovered from two Spanish hospitals. The aim of this study was to characterize the resistance mechanisms of these strains and to determine their clonal relationships.

\section{METHODS}

Strains and patients. Three VREF-VBP clinical strains (E. faecium C393, C395 and C461) were recovered from blood and urine 
samples from three patients from the Miguel Servet Hospital in Zaragoza, Spain (Table 1). MIC values of vancomycin and teicoplanin for these strains (16 and $0.5 \mu \mathrm{g} \mathrm{ml}^{-1}$, respectively) were indicative of the VanB-resistant phenotype. They were detected among a series of 1036 clinical enterococcal isolates recovered over a 1 year period (February 2002 to January 2003) in that hospital (0.3\%). An additional VREF-VBP clinical strain (E. faecium C396) was recovered in March 2002 from the abdominal abscess of a patient from Royo Villanova Hospital, located $4 \mathrm{~km}$ away from Miguel Servet Hospital. Relationships among the patients from the two hospitals were not known.

In order to detect intestinal colonization by VREF-VBP strains, a surveillance programme was carried out with all faecal samples $(n=632)$ collected in Miguel Servet Hospital from February to June 2002. Faecal samples were diluted in sterile saline solution and seeded in bile aesculin agar plates supplemented with vancomycin $\left(6 \mu \mathrm{g} \mathrm{ml}^{-1}\right)$ and aztreonam $\left(75 \mu \mathrm{g} \mathrm{ml}^{-1}\right)$. Colonies with a typical enterococcal morphology were identified by classical biochemical methods and putative enterococci were verified using specific PCR assays (Table 2). Four of these 632 faecal samples $(0.6 \%)$ were shown to be colonized by VREF-VBP strains (E. faecium C397, C402, C404 and C406). In addition, from July 2002 to January 2003, sporadic faecal samples from particular patients [confined in the intensive care unit (ICU) and oncology wards, among others] were also analysed for this purpose in Miguel Servet Hospital and one additional VREF-VBP strain was collected (E. faecium C460) (Table 1).

The nine VREF-VBP strains included in this study, implicated in infection processes (four strains) or in intestinal colonization (five strains), were recovered from nine different patients from these two Spanish hospitals (Table 1). All patients had severe diseases and six were or had been admitted to an ICU ward of the hospital. Five had been treated previously with glycopeptides, whilst two others had received broad-spectrum antibiotics, such as imipenem or ceftazidime. No information about previous antibiotic consumption was available for the remaining two patients.

Antibiotic susceptibility testing. Determination of the MICs of different antibiotics (vancomycin, teicoplanin, streptomycin, gentamicin, kanamycin, ampicillin, erythromycin, ciprofloxacin, tetracycline and chloramphenicol) was carried out using the NCCLS agar dilution method (NCCLS, 2002). E. faecalis ATCC 29212 and Staphylococcus aureus ATCC 25923 were used as control strains.

Characterization of the vancomycin resistance mechanism. Vancomycin resistance mechanisms were analysed in VREF-VBP strains using specific primers for amplification of the vanA, vanC-1, vanC-2/3 and vanD genes (Table 2). E. faecium AR1 and E. faecalis SF300 (kindly supplied by E. Cercenado, Hosp. Gregorio Marañón, Madrid, Spain) were used as positive controls for the vanA and vanB PCR assays, respectively (Gold et al., 1993; Torres et al., 1994). Enterococcus gallinarum Z380 and Enterococcus casseliflavus Z406, from the collection of strains of the University of La Rioja, were used as positive controls for PCR detection of the vanC-1 and vanC$2 / 3$ genes, respectively. vanB ligase genes, as well as the intergenic van $S_{\mathrm{B}}-v a n Y_{\mathrm{B}}$ region, were amplified by PCR. In order to determine whether the vanB2 operon of the vanB2-positive strains was associated with a Tn5382-like element, specific primers for the non-integrase (left) end of Tn5382 and for the $\operatorname{van} X_{\mathrm{B}}-O R F C$ intergenic region and flanking coding sequences in Tn 5382 were used for PCR assays. The same strains were examined for $p b p 5-\mathrm{Tn} 5382$ linkage by PCR amplifying a $1079 \mathrm{bp}$ region between $p b p 5$ and Tn5382. Subsequent sequence analysis of PCR products was performed for all PCR assays mentioned above. PCR primers and conditions, as well as the relevant references, are given in Table 2.
Detection of other antibiotic resistance or virulence genes. The presence of other resistance genes, such as aac (6')-Ie-aph $\left(2^{\prime \prime}\right)-I a$, $\operatorname{aph}\left(3^{\prime}\right)-I I I a, \operatorname{ant}(6)-I a, \operatorname{erm}(\mathrm{A}), \operatorname{erm}(\mathrm{B})$ and $\operatorname{erm}(\mathrm{C})$, was analysed by specific PCRs using primers and conditions reported previously (Table 2). In addition, the presence of the esp and hyl genes (encoding an enterococcal surface protein and hyaluronidase, respectively) was also studied and positive amplicons were sequenced for confirmation. Positive and negative controls from our collection of strains were included in all PCR assays.

Mating experiments. The transferability of vancomycin resistance genetic determinants was tested by conjugation using a filter-mating method (Dunny et al., 1979), with E. faecalis strain JH2-2 as recipient (rifampicin- and fusidic acid-resistant, vancomycin-susceptible) and two VREF-VBP strains (C393 and C461) as donors (fusidic acid-susceptible, vancomycin-resistant). Vancomycin-resistant transconjugants were selected on brain heart infusion agar plates supplemented with fusidic acid $\left(25 \mu \mathrm{g} \mathrm{ml}^{-1}\right)$ and vancomycin $\left(5 \mu \mathrm{g} \mathrm{ml}^{-1}\right)$.

PFGE analysis of VREF-VBP strains. The clonal relationships of the nine vanB2-containing E. faecium strains were studied by PFGE by analysing their genomic DNA after digestion with SmaI (New England Biolabs), as reported previously (Turabelidze et al., 2000). This technique was performed using clamped homogeneous electric fields (CHEF DRII; Bio-Rad). The running parameters were as follows: voltage, $6 \mathrm{~V} \mathrm{~cm}^{-1}$; block 1: run time $12 \mathrm{~h}$; initial switch time $3.5 \mathrm{~s}$; final switch time $25 \mathrm{~s}$; block 2 : run time $8 \mathrm{~h}$; initial switch time $1 \mathrm{~s}$; final switch time $5 \mathrm{~s}$. A bacteriophage $\lambda$ ladder (Bio-Rad) was used as a size marker. PFGE banding patterns were analysed and compared visually. Isolates were classified as indistinguishable, closely related, possibly related or unrelated by following previously defined criteria for bacterial strain typing (Tenover et al., 1995).

\section{RESULTS AND DISCUSSION}

All nine of the VREF-VBP strains of clinical and intestinal origin included in this study showed low-level vancomycin resistance (MIC $16-32 \mu \mathrm{g} \mathrm{ml}^{-1}$ ) and susceptibility to teicoplanin (MIC $0.5 \mu \mathrm{g} \mathrm{ml}^{-1}$ ). Positive PCR assays were obtained with the consensus $v a n B$ primers for the nine strains, showing negative results for the remaining vanA, vanC-1, van $C-2 / 3$ and vanD PCR tests. Nucleotide sequences of the $v a n B$ amplicons revealed the presence of the vanB2 subtype in all nine strains (Table 1) and they were $100 \%$ identical to that previously reported for the vanB2 gene in human and animal enterococcal isolates (Garnier et al., 2000; Gold et al., 1993; Torres et al., 2003).

According to the PFGE analysis, two possibly related PFGE patterns, A (seven strains) and B (two strains), could be distinguished (Table 1 and Fig. 1). Curiously, strains of PFGE pattern A were recovered at the beginning of the study (from seven patients of the two hospitals from February to May 2002), whilst strains belonging to PFGE pattern B were isolated at the end of the study (from two patients of Miguel Servet Hospital in December 2002 and January 2003).

Sequencing of the $v a n S_{\mathrm{B}}-Y_{\mathrm{B}}$ intergenic regions for the nine vanB2-containing strains showed the typical 11 point mutations and the $5 \mathrm{bp}$ deletion of the vanB2 subtype (Dahl et al., 2000). All of the strains showed positive PCR results for Tn5382 and the sequences obtained showed 
Table 1. Characteristics of the VREF strains included in this study and of the patients from whom they were recovered

\begin{tabular}{|c|c|c|c|c|c|c|c|c|c|c|}
\hline \multicolumn{7}{|c|}{ Characteristics of the strains } & \multicolumn{4}{|c|}{ Characteristics of the patients } \\
\hline \multirow[t]{2}{*}{ VREF strain } & \multirow{2}{*}{$\begin{array}{c}\text { Source } \\
\text { and isolation } \\
\text { date (month/year) }\end{array}$} & \multirow{2}{*}{$\begin{array}{c}\text { VAN } \\
\text { resistance } \\
\text { mechanism }\end{array}$} & \multicolumn{2}{|c|}{$\begin{array}{c}\mathrm{MIC}^{\star} \\
\left(\mu \mathrm{g} \mathrm{ml}^{-1}\right)\end{array}$} & \multirow{2}{*}{$\begin{array}{c}\text { Resistance } \\
\text { to other } \\
\text { antibiotics }\end{array}$} & \multirow[t]{2}{*}{$\begin{array}{l}\text { PFGE } \\
\text { pattern }\end{array}$} & \multirow[t]{2}{*}{ Pathology } & \multirow{2}{*}{$\begin{array}{c}\text { Previous } \\
\text { exposure } \\
\text { in ICU ward }\end{array}$} & \multirow{2}{*}{$\begin{array}{c}\text { Previous } \\
\text { antibiotic } \\
\text { treatment }^{*}\end{array}$} & \multirow[t]{2}{*}{ Hospital } \\
\hline & & & VAN & TEI & & & & & & \\
\hline \multicolumn{11}{|c|}{ Clinical infection } \\
\hline C393 & Blood $(2 / 02)$ & vanB2 & 16 & $0 \cdot 5$ & STR-KAN-AMP-ERY-CIP & A & Kidney failure & No & VAN & MS \\
\hline C395 & Urine $(3 / 02)$ & vanB2 & 16 & $0 \cdot 5$ & STR-KAN-AMP-ERY-CIP & A & Peritonitis & Yes & Glycopeptides & MS \\
\hline C461 & Urine $(1 / 03)$ & vanB2 & 16 & $0 \cdot 5$ & STR-KAN-AMP-ERY-TET-CIP & B & Heart surgery & Yes & Unknown & MS \\
\hline C396 & $\begin{array}{l}\text { Abdominal abscess } \\
(3 / 02)\end{array}$ & vanB2 & 16 & $0 \cdot 5$ & STR-KAN-AMP-ERY-CIP & A & Intestinal surgery & No & Unknown & $\mathrm{RV}$ \\
\hline \multicolumn{11}{|c|}{ Intestinal colonization } \\
\hline C397 & Faeces $(4 / 02)$ & vanB2 & 16 & $0 \cdot 5$ & STR-KAN-AMP-ERY-CIP & A & Heart surgery & Yes & $\begin{array}{l}\text { Glycopeptides } \\
\text { and others }\end{array}$ & MS \\
\hline C402 & Faeces $(4 / 02)$ & vanB2 & 16 & $0 \cdot 5$ & STR-KAN-AMP-ERY-CIP & A & Heart surgery & Yes & CAZ and others & MS \\
\hline C404 & Faeces $(5 / 02)$ & vanB2 & 16 & $0 \cdot 5$ & STR-KAN-AMP-ERY-CIP & A & Lung disease & Yes & TEI and FEP & MS \\
\hline C406 & Faeces $(5 / 02)$ & vanB2 & 16 & $0 \cdot 5$ & STR-KAN-AMP-ERY-CIP & A & Heart surgery & Yes & VAN & MS \\
\hline $\mathrm{C} 460$ & Faeces $(12 / 02)$ & vanB2 & 32 & $0 \cdot 5$ & STR-KAN-AMP-ERY-TET-CIP & B & $\begin{array}{l}\text { Human immuno- } \\
\text { deficiency virus }\end{array}$ & No & IPM and others & MS \\
\hline
\end{tabular}

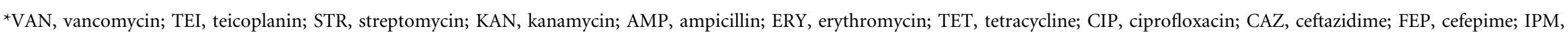
imipenem. High-level resistance was assumed for aminoglycosides. 
Table 2. Primers and conditions used in PCR reactions in this study

\begin{tabular}{|c|c|c|c|c|c|}
\hline Gene or fragment amplified & Primer name & Primer sequence $\left(5^{\prime} \rightarrow 3^{\prime}\right)$ & $T_{\mathrm{a}}\left({ }^{\circ} \mathrm{C}\right)^{*}$ & Product size (bp) & Reference \\
\hline \multirow[t]{2}{*}{ vanA } & $\operatorname{van} A-1$ & GGG AAA ACG ACA ATT GC & 54 & 732 & Dutka-Malen et al. (1995) \\
\hline & $\operatorname{van} A-2$ & GTA CAA TGC GGC CGT TA & & & \\
\hline $\operatorname{van} B$ consensus & vanB-1 & CAA AGC TCC GCA GCT TGC ATG & 58 & 484 & Dahl et al. (1999) \\
\hline \multirow[t]{2}{*}{$\operatorname{van} C-1$} & $\operatorname{vanC1-1}$ & GCT GAA ATA TGA AGT AAT GAC CA & 58 & 811 & Miele et al. (1995) \\
\hline & $\operatorname{vanC1-2}$ & CGG CAT GGT GTT GAT TTC GTT & & & \\
\hline \multirow[t]{2}{*}{$\operatorname{van} C-2 / 3$} & $\operatorname{van} C 2 / 3-1$ & CTC CTA CGA TTC TCT TG & 54 & 439 & Dutka-Malen et al. (1995) \\
\hline & $\operatorname{van} C 2 / 3-2$ & CGA GCA AGA CCT TTA AG & & & \\
\hline \multirow[t]{2}{*}{$\operatorname{van}_{\mathrm{B}}-\operatorname{van}_{\mathrm{B}}$} & $\operatorname{vanS}_{\mathrm{B}} Y_{\mathrm{B}}-1$ & ATA TGC GCT GGA AAA CAC CTC & 60 & 309 & Dahl et al. (1999) \\
\hline & $\operatorname{vanS}_{\mathrm{B}} Y_{\mathrm{B}}-2$ & CCC CAG ATT GTT TCA TAT GCC & & & \\
\hline \multirow[t]{2}{*}{ Tn5382-like } & Tn5382-1 & GTT CTT ATT CCG CAG GTG GTG ATT & 60 & 311 & Carias et al. (1998) \\
\hline & $\operatorname{Tn} 5382-2$ & ACG CCA TGC TAT TTA CTT CCG GC & & & Dahl et al. (2000) \\
\hline \multirow[t]{2}{*}{$\operatorname{van} X_{\mathrm{B}}-\mathrm{ORFC}$} & $\operatorname{van} X_{\mathrm{B}}-O R F C-1$ & GAT GCC AAG TAC GCT ACA TGG GA & 57 & 873 & Carias et al. (1998) \\
\hline & $\operatorname{van} X_{\mathrm{B}}-O R F C-2$ & TGA GTT GTG GAA GTC GAT TAG AG & & & Dahl et al. (2000) \\
\hline$p b p 5-\operatorname{Tn} 5382$ & pbp5-Tn5382-1 & TCA GCC GAT TTG CGA CAG GTT ATG & 55 & 1079 & Carias et al. (1998) \\
\hline $\operatorname{aac}\left(6^{\prime}\right)-\operatorname{Ie}-a p h\left(2^{\prime \prime}\right)-I a$ & $a a c\left(6^{\prime}\right)-I e-a p h\left(2^{\prime \prime}\right)-I a-2$ & CAC TAT CAT AAC CAC TAC CG & & & \\
\hline \multirow[t]{2}{*}{$a p h\left(3^{\prime}\right)-I I I a$} & $\operatorname{aph}\left(3^{\prime}\right)-I I I a-1$ & GCC GAT GTG GAT TGC GAA AA & 60 & 292 & Van de Klundert \& Vliegenthart (1993) \\
\hline & $\operatorname{aph}\left(3^{\prime}\right)-I I I a-2$ & GCT TGA TCC CCA GTA AGT CA & & & \\
\hline \multirow[t]{2}{*}{$\operatorname{erm}(\mathrm{A})$} & $\operatorname{erm}(\mathrm{A})-1$ & TCT AAA AAG CAT GTA AAA GAA & 52 & 645 & Sutcliffe et al. (1996) \\
\hline & $\operatorname{erm}(\mathrm{A})-2$ & CTT CGA TAG TTT ATT AAT ATT AGT & & & \\
\hline \multirow[t]{2}{*}{$\operatorname{erm}(\mathrm{B})$} & $\operatorname{erm}(\mathrm{B})-1$ & GAA AAG GTA CTC AAC CAA ATA & 52 & 639 & Sutcliffe et al. (1996) \\
\hline & $\operatorname{erm}(\mathrm{B})-2$ & AGT AAC GGT ACT TAA ATT GTT TAC & & & \\
\hline \multirow[t]{2}{*}{$\operatorname{erm}(\mathrm{C})$} & $\operatorname{erm}(\mathrm{C})-1$ & TCA AAA CAT AAT ATA GAT AAA & 52 & 642 & Sutcliffe et al. (1996) \\
\hline & $\operatorname{erm}(\mathrm{C})-2$ & GCT AAT ATT GTT TAA ATC GTC AAT & & & \\
\hline \multirow[t]{2}{*}{$\operatorname{tet}(\mathrm{M})$} & $\operatorname{tet}(\mathrm{M})-1$ & GTT AAA TAG TGT TCT TGG AG & 55 & 696 & Aarestrup et al. (2000) \\
\hline & $\operatorname{tet}(\mathrm{M})-2$ & CTA AGA TAT GGC TCT AAC AA & & & \\
\hline \multirow[t]{2}{*}{ esp } & $e s p-1$ & CTT TGA TTC TTG GTT GTC GGA TAC & 55 & 475 & Klare et al. (2005) \\
\hline & esp-2 & TTC AAC TAC CAC GGT TTG TTT ATC & & & \\
\hline$h y l$ & $h y l-1$ & GAG TAG AGG AAT ATC TTA GC & 50 & 661 & Klare et al. (2005) \\
\hline
\end{tabular}




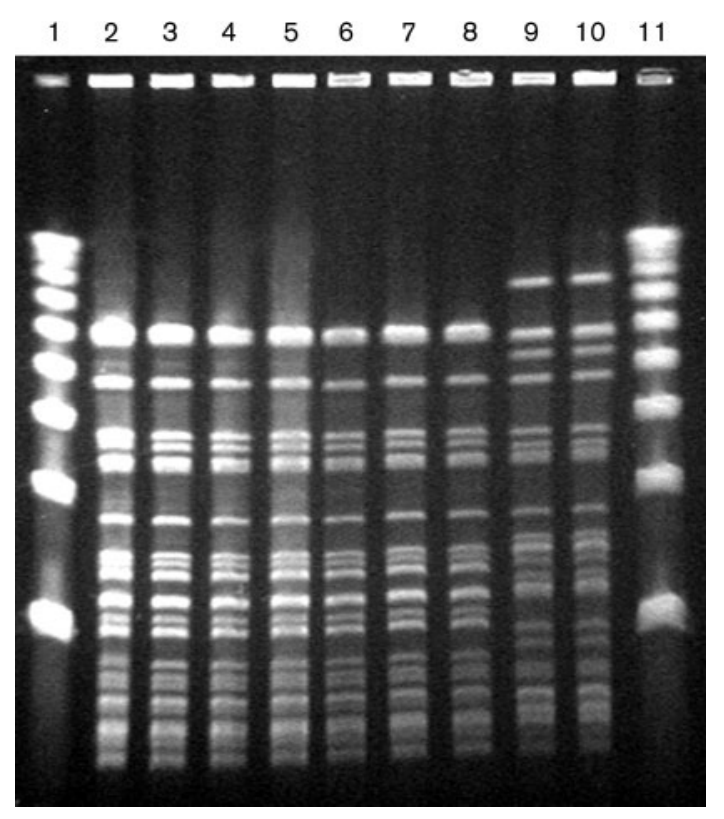

Fig. 1. PFGE of Smal-digested genomic DNA from the nine vanB2 E. faecium strains. Lanes: 1 and 11, PFGE DNA marker; 2, E. faecium C393; 3, E. faecium C395; 4, E. faecium C396, 5, E. faecium C397; 6, E. faecium C402; 7, E. faecium C404; 8, E. faecium C406; 9, E. faecium C460; 10, E. faecium C461.

$100 \%$ identity with a partial sequence of the previously reported Tn5382 and Tn1549 transposons (GenBank accession nos AF175739 and AF192329, respectively). These sequences were also $100 \%$ identical to that previously found by our group in a vanB2-containing E. hirae strain of animal origin (Torres et al., 2003). However, slight differences for the van $X_{\mathrm{B}}-O R F C$ amplicons of the nine strains were observed. The seven strains belonging to PFGE pattern A showed a sequence $100 \%$ identical to that reported previously for vanB2-containing E. faecalis and $E$. faecium strains with the Tn5382 transposon (GenBank accession nos AF203411 and AF203417, respectively). Nevertheless, a different sequence with a deduced valine residue (codon GTG) at position 46 of the $\mathrm{VanX}_{\mathrm{B}}$ protein and an asparagine residue (codon AAT) at position 89 was obtained for the remaining two strains with the PFGE pattern B (E. faecium $\mathrm{C} 460$ and C461). This VanX $\mathrm{X}_{\mathrm{B}}$ sequence was $100 \%$ identical to that previously reported for other vanB2-containing E. faecium strains with Tn5382 (GenBank accession no. AF203412 and others) and also identical to that found in the vanB2 E. hirae strain of animal origin previously published (Torres et al., 2003). The impact of these amino acid changes on the activity of the $\operatorname{VanX}_{B}$ protein remains to be investigated. According to our results, the vanB2 gene cluster could be included in a Tn5382-like element in our strains. It should be noted that Tn5382 and Tn 1549 show a strong similarity at both ends of the transposons (Carias et al., 1998; Garnier et al., 2000; Umeda et al., 2002) and it has been proposed that both could be integrated in the Tn5382-Tn1549 family (Umeda et al., 2002).

According to a recent report, vanB2-containing E. faecium strains from Taiwan were found to harbour Tn5382 and to be associated with the pbp5 gene ( $\mathrm{Lu}$ et al., 2005). In our study, the nine VREF-VBP strains showed ampicillin resistance and using PCR it was possible to detect the presence of pbp5-Tn5382 amplicons of the expected size in all of them. Two of these amplicons were sequenced $(E$. faecium C395 and C393), confirming that sequences of Tn5382 were located downstream from a $p b p 5$ gene. The sequence of the C-terminal part of the protein encoded by $p b p 5$ in these two isolates presented nine amino acid changes with respect to the deduced sequence of the protein encoded by pbp5 (GenBank accession no. X84860) (Jureen et al., 2003). The amino acid changes detected in the protein encoded by the $p b p 5$ gene in both isolates were: $461 \mathrm{Q} \rightarrow \mathrm{K}$, $470 \mathrm{H} \rightarrow \mathrm{Q}, \quad 485 \mathrm{M} \rightarrow \mathrm{A}, \quad 496 \mathrm{~N} \rightarrow \mathrm{K}, \quad 499 \mathrm{~A} \rightarrow \mathrm{T}, \quad 525 \mathrm{E} \rightarrow \mathrm{D}$, $586 \mathrm{~V} \rightarrow \mathrm{L}, 629 \mathrm{E} \rightarrow \mathrm{V}$ and $667 \mathrm{P} \rightarrow \mathrm{S}$. Most of these amino acid changes have been detected previously in the protein encoded by the $p b p 5$ gene of ampicillin-resistant E. faecium isolates (Jureen et al., 2003; Rice et al., 2004).

The transferability of genetic determinants implicated in vancomycin resistance was tested by conjugation using $E$. faecium C393 (pattern A) or C461 (pattern B) as donor and E. faecalis strain $\mathrm{JH} 2-2$ as recipient. Results were negative in both cases and no transconjugants were detected.

The presence of the esp and hyl genes encoding virulence factors (enterococcal surface protein and hyaluronidase, respectively) was investigated by PCR and sequencing. The esp gene was detected in the two vanB2-containing $E$. faecium strains belonging to PFGE pattern $B$, but not in those of pattern A. The hyl gene was not identified in our VREF-VRP strains. The clonal spread of ampicillin/ vancomycin-resistant E. faecium carrying the esp and $h y l$ genes in German hospitals has been reported recently (Klare et al., 2005).

All of the strains in this study showed high-level streptomycin and kanamycin resistance, as well as resistance to erythromycin and ciprofloxacin. The two strains included in the PFGE pattern B also showed tetracycline resistance. The ant $\left(6^{\prime}\right)-I a, a p h\left(3^{\prime}\right)$-IIIa and erm(B) genes were detected in all nine strains.

In conclusion, this study reports for the first time the persistence of clonally related vanB2-containing E. faecium strains affecting patients in two hospitals in the same city in Spain. A previous clinical vanB2-containing E. faecium strain was detected in a Spanish hospital by other authors (Lorenzo-Díaz et al., 2004) and very recently a nosocomial outbreak of vanB2 vancomycin-resistant $E$. faecium was reported in Sweden (Granlund et al., 2006). In most cases, our vancomycin-resistant enterococci were recovered from patients with severe diseases (the majority had been hospitalized in ICU wards) who had previously received 
glycopeptides and other broad-spectrum antibiotics. Special care should be taken in the future to ensure the rapid detection and control of this type of strain in order to avoid its dissemination within a hospital.

\section{ACKNOWLEDGEMENTS}

This work was supported in part by a grant from the Fondo de Investigaciones Sanitarias of Spain (FIS 01/973).

\section{REFERENCES}

Aarestrup, F. M., Agerso, Y., Gerner-Smidt, P., Madsen, M. \& Jensen, L. B. (2000). Comparison of antimicrobial resistance phenotypes and resistance genes in Enterococcus faecalis and Enterococcus faecium from humans in the community, broilers, and pigs in Denmark. Diagn Microbiol Infect Dis 37, 127-137.

Carias, L. L., Rudin, S. D., Donskey, C. J. \& Rice, L. B. (1998). Genetic linkage and cotransfer of a novel vanB-containing transposon (Tn5382) and a low-affinity penicillin-binding protein 5 gene in a clinical vancomycin-resistant Enterococcus faecium isolate. J Bacteriol 180, 4426-4434.

Cetinkaya, Y., Falk, P. \& Mayhall, C. G. (2000). Vancomycin-resistant enterococci. Clin Microbiol Rev 13, 686-707.

Clark, N. C., Olsvik, Ø., Swenson, J. M., Spiegel, C. A. \& Tenover, F. C. (1999). Detection of a streptomycin/spectinomycin adenylyltransferase gene (aadA) in Enterococcus faecalis. Antimicrob Agents Chemother 43, 157-160.

Dahl, K. H., Simonsen, G. S., Olsvik, Ø. \& Sundsfjord, A. (1999). Heterogeneity in the $v a n B$ gene cluster of genomically diverse clinical strains of vancomycin-resistant enterococci. Antimicrob Agents Chemother 43, 1105-1110.

Dahl, K. H., Lundblad, E. W., Rokenes, T. P., Olsvik, Ø. \& Sundsfjord, A. (2000). Genetic linkage of the vanB2 gene cluster to Tn5382 in vancomycin-resistant enterococci and characterization of two novel insertion sequences. Microbiology 146, 1469-1479.

Domingo, M.-C., Huletsky, A., Bernal, A., Giroux, R., Boudreau, D. K., Picard, F. J. \& Bergeron, M. G. (2005). Characterization of a Tn5382like transposon containing the vanB2 gene cluster in a Clostridium strain isolated from human faeces. J Antimicrob Chemother 55, 466-474.

Dunny, G. M., Craig, R. A., Carron, R. L. \& Clewell, D. B. (1979). Plasmid transfer in Streptococcus faecalis: production of multiple sex pheromones by recipients. Plasmid 2, 454-465.

Dutka-Malen, S., Evers, S. \& Courvalin, P. (1995). Detection of glycopeptide resistance genotypes and identification to the species level of clinically relevant enterococci by PCR. J Clin Microbiol 33, 24-27.

Garnier, F., Taourit, S., Glaser, P., Courvalin, P. \& Galimand, M. (2000). Characterization of transposon Tn1549, conferring VanBtype resistance in Enterococcus spp. Microbiology 146, 1481-1489.

Gholizadeh, Y. \& Courvalin, P. (2000). Acquired and intrinsic glycopeptide resistance in enterococci. Int J Antimicrob Agents 16, S11-S17.

Gold, H. S., Ünal, S., Cercenado, E., Thauvin-Eliopoulos, C., Eliopoulos, G. M., Wennersten, C. B. \& Moellering, R. C., Jr (1993). A gene conferring resistance to vancomycin but not teicoplanin in isolates of Enterococcus faecalis and Enterococcus faecium demonstrates homology with vanB, vanA, and vanC genes of enterococci. Antimicrob Agents Chemother 37, 1604-1609.
Granlund, M., Carlsson, C., Edebro, H., Emanuelsson, K. \& Lundholm, R. (2006). Nosocomial outbreak of vanB2 vancomycinresistant Enterococcus faecium in Sweden. J Hosp Infect 62, 254-256. Jureen, R., Top, J., Mohn, S. C., Harthug, S., Langeland, N. \& Willens, R. J. L. (2003). Molecular characterization of ampicillinresistant Enterococcus faecium isolates from hospitalized patients in Norway. J Clin Microbiol 41, 2330-2336.

Kawalec, M., Gniadkowski, M., Zielinska, U., Klos, W. \& Hryniewicz, W. (2001). Vancomycin-resistant Enterococcus faecium strain carrying the vanB2 gene variant in a Polish hospital. J Clin Microbiol 39, 811-815.

Klare, I., Konstabel, C., Mueller-Bertling, S. \& 10 other authors (2005). Spread of ampicillin/vancomycin-resistant Enterococcus faecium of the epidemic-virulent clonal complex-17 carrying the genes esp and hyl in German hospitals. Eur J Clin Microbiol Infect Dis 24, 815-825.

Lee, W. G., Jernigan, J. A., Rashed, J. K., Anderson, G. J. \& Tenover, F. C. (2001). Possible horizontal transfer of the vanB2 gene among genetically diverse strains of vancomycin-resistant Enterococcus faecium in a Korean hospital. J Clin Microbiol 39, 1165-1168.

Lorenzo-Díaz, F., Delgado, T., Reyes-Darias, J. A., Flores, C., Méndez-Álvarez, S., Villar, J., Sierra, A. \& Claverie-Martín, F. (2004). Characterization of the first VanB vancomycin-resistant Enterococcus faecium isolated in a Spanish hospital. Curr Microbiol 48, 199-203.

Lu, J.-J., Perng, C.-L., Ho, M.-F., Chiueh, T.-S. \& Lee, W.-H. (2001). High prevalence of VanB2 vancomycin-resistant Enterococcus faecium in Taiwan. J Clin Microbiol 39, 2140-2145.

Lu, J.-J., Chang, T.-Y., Perng, C.-L. \& Lee, S.-Y. (2005). The vanB2 gene cluster of the majority of vancomycin-resistant Enteroccus faecium isolates from Taiwan is associated with the $p b p 5$ gene and is carried by Tn 5382 containing a novel insertion sequence. Antimicrob Agents Chemother 49, 3937-3939.

Mato, R., de Lencastre, H., Roberts, R. B. \& Tomasz, A. (1996). Multiplicity of genetic backgrounds among vancomycin-resistant Enterococcus faecium isolates recovered from an outbreak in a New York City hospital. Microb Drug Resist 2, 309-317.

McGregor, K. F. \& Young, H.-K. (2000). Identification and characterization of vanB2 glycopeptide resistance elements in enterococci isolated in Scotland. Antimicrob Agents Chemother 44, 2341-2348.

McGregor, K. F., Nolan, C., Young, H.-K., Palepou, M.-F. I., Tysall, L. \& Woodford, N. (2001). Prevalence of the vanB2 gene cluster in the VanB glycopeptide-resistant enterococci in the United Kingdom and the Republic of Ireland and its association with a Tn5382-like element. Antimicrob Agents Chemother 45, 367-368.

Miele, A., Bandera, M. \& Goldstein, B. P. (1995). Use of primers selective for vancomycin resistance genes to determine van genotype in enterococci and to study gene organization in VanA isolates. Antimicrob Agents Chemother 39, 1772-1778.

Murray, B. (1997). Vancomycin-resistant enterococci. Am J Med 102, 284-293.

NCCLS (2002). Methods for dilution antimicrobial susceptibility tests for bacteria that grow aerobically. NCCLS document M7-A5. Wayne, PA: National Committee for Clinical Laboratory Standards.

Perichon, B., Reynolds, P. \& Courvalin, P. (1997). VanD-type glycopeptide-resistant Enterococcus faecium BM4339. Antimicrob Agents Chemother 41, 2016-2018.

Quintiliani, R., Jr, Evers, S. \& Courvalin, P. (1993). The vanB gene confers various levels of self-transferable resistance to vancomycin in enterococci. J Infect Dis 167, 1220-1223.

Rice, L. B., Bellais, S., Carias, L. L., Hutton-Thomas, R., Bonomo, R. A., Caspers, P., Page, M. G. P. \& Gutmann, L. (2004). Impact of 
specific $p b p 5$ mutations on expression of $\beta$-lactam resistance in Enterococcus faecium. Antimicrob Agents Chemother 48, 3028-3032.

Simonsen, G. S., Andersen, B. M., Digranes, A. \& 9 other authors (1998). Low faecal carrier rate of vancomycin resistant enterococci in Norwegian hospital patients. Scand J Infect Dis 30, 465-468.

Sutcliffe, J., Grebe, T., Tait-Kamradt, A. \& Wondrack, L. (1996). Detection of erythromycin-resistant determinants by PCR. Antimicrob Agents Chemother 40, 2562-2566.

Tenover, F. C., Arbeit, R. D., Goering, R. V., Mickelsen, P. A., Murray, B. E., Persing, D. H. \& Swaminathan, B. (1995). Interpreting chromosomal DNA restriction patterns produced by pulsed-field gel electrophoresis: criteria for bacterial strain typing. J Clin Microbiol 33, 2233-2239.

Torres, C., Reguera, J. A., Sanmartín, M. J., Pérez-Díaz, J. C. \& Baquero, F. (1994). vanA-mediated vancomycin-resistant Enterococcus spp. in sewage. J Antimicrob Chemother 33, 553-561.

Torres, C., Tenorio, C., Portillo, A., García, M., Martínez, C., del Campo, R., Ruiz-Larrea, F. \& Zarazaga, M. (2003). Intestinal colonization by vanA- or vanB2-containing enterococcal isolates of healthy animals in Spain. Microb Drug Resist 9 (Suppl. 1), S47-S52.

Turabelidze, D., Kotetishvili, M., Krefer, A., Morris, J. G. \& Sulakvelidze, A. (2000). Improved pulsed-field gel electrophoresis for typing vancomycin-resistant enterococci. J Clin Microbiol 38, 4242-4245.

Umeda, A., Garnier, F., Courvalin, P. \& Galimand, M. (2002). Association between the vanB2 glycopeptide resistance operon and Tn1549 in enterococci from France. J Antimicrob Chemother 50, 253-256.

Van de Klundert, J. A. M. \& Vliegenthart, J. S. (1993). PCR detection of genes for aminoglycoside-modifying enzymes. In Diagnostic Molecular Microbiology: Principles and Applications, pp. 547-552. Edited by D. H. Persing, T. F. Smith, F. C. Tenover \& T. J. White. Washington, DC: American Society for Microbiology.

Woodford, N. (2001). Epidemiology of the genetic elements responsible for acquired glycopeptide resistance in enterococci. Microb Drug Resist 7, 229-236. 